
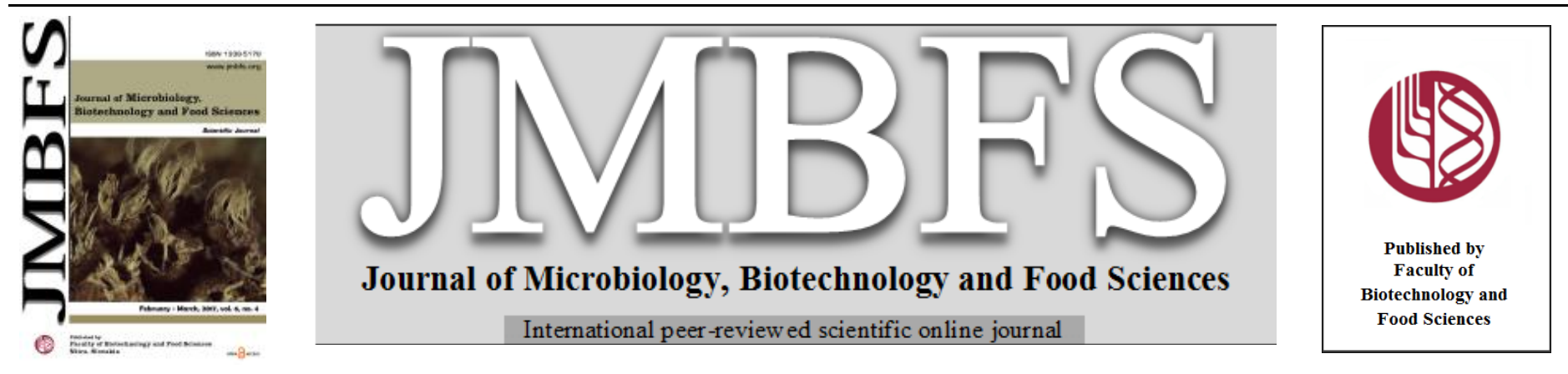

\title{
IMPACT OF CHEESE WHEY PROTEIN ON GROWTH PERFORMANCE OF BROILER: AN APPROACH OF CHEESE WHEY UTILIZATION IN POULTRY FEED
}

\author{
Kanza $^{l}$, Majid Majeed ${ }^{l}$,Aysha Sameen ${ }^{1} *$, Muhammad Usman khan ${ }^{2}$, Mohammad Ali Shariati $^{3}$, Vesna Karapetkovska - Hristova ${ }^{4}$
}

$\operatorname{Address}(e s):$

${ }^{1}$ National Institute of Food Science and Technology, University of Agriculture, Faisalabad (Pakistan).

${ }^{2}$ Department of Energy Systems Engineering, University of Agriculture Faisalabad,38000,Faisalabd,Pakistan.

${ }^{3}$ Research Department, LLC «Science \& Education», Russia and Researcher All Russian Research Institute of Phytopathology, Moscow Region, Russia.

${ }^{4}$ Department of biotechnology, Faculty of biotechnical sciences - Bitola, University "St. KlimentOhridski", Republic of Macedonia.

*Corresponding author: Kanza47@yahoo.com

doi: 10.15414/jmbfs.2017.6.4.1117-1120

ARTICLE INFO

Received 16. 11. 2016

Revised 20. 12. 2016

Accepted 5. 1. 2017

Published 1. 2. 2017

Regular article

open 2 access

\begin{abstract}
Cheese whey is greenish yellow liquid separated during cheese processing. It accounts $80-90 \%$ of milk after cheese processing. It is usually wasted by cheese industries, particularly in developing countries like Pakistan that increases BOD and COD of dairy effluent. Various useful components like lactose, proteins, minerals etc. are present in whey. Among proteins, whey proteins are very effective in body muscle anabolism along with other health benefits. Present research utilized whey proteins in the form of protein supplement. Whey protein was precipitated by combination of $\mathrm{pH}$, temperature and salt treatment followed by filtration. Two types of whey protein concentrates (WPCs) were formed. One was creamy textured while the other was in powder form. WPCs were added in broiler feed at the rate of $0.2 \%$ in powder form and $2 \%$ in the creamy texture form. Growth parameters like feed consumption, body weight and weight gain increased with whey protein supplement while had no effect on feed conversion ratio (FCR). Carcass traits like carcass, breast, thigh, wings, drumstick weight had significantly increased with the incorporation of whey protein while having non-significant effect on liver weight, GIT weight and GIT/carcass ratio. Whey protein supplementation exhibit no significant influence on packed cell volume (PCV), hemoglobin, lymphocytes and polymorphnuclear leukocyte (PMN) while exhibit significant impact on leukocytes and platelets. It is concluded that only $0.2 \%$ WPC (powder) exhibit significant impact on carcass growth while 2\% WPC (creamy texture) supplementation improved the growth parameters but statistical analysis revealed it non-significant.
\end{abstract}

Keywords: Whey, Whey Protein Concentrates (WPCs), Muscle anabolism, Essential amino acid, Fast protein, Hematology

\section{INTRODUCTION}

The dairy industry is divided into various sectors and each sector produces different kinds of products. Milk, Yoghurt, cheese, butter and ice-cream are common products of dairy industries. During processing of these products different effluents are produced. Each effluent has different characteristics depending upon the process and the product. All these effluents increase biological oxygen demand (BOD) and chemical oxygen demand (COD) of water, when discharged untreated.

Whey is one of the dairy effluents formed during cheese processing. It accounts $80-90 \%$ of total milk volume. Apart from being valued as a medicinal agent in the $17^{\text {th }}$ and $18^{\text {th }}$ centuries, whey has primarily been considered a waste by the dairy industry. In the late 20th century, regulations prevented the disposal of untreated whey. At the same time, recognition of the value of whey components accelerated. Modern science has unraveled the secrets of whey proteins and other whey components, and established a sound basis for their nutritional and functional value. Now it is possible to conserve valuable whey components, including lactose, proteins and minerals that results a variety of products available in the market (Smither, 2008).

Whey protein is one of the important components of whey. It is one of the two major proteins of milk that accounts $20 \%$ of total milk protein while the rest $80 \%$ is casein. Most of casein protein becomes the part of the cheese during cheese production while whey proteins left in the whey (the liquid left after cheese production). Whey protein is a protein complex which contains many kinds of proteins and enzymes like beta-lactoglobulin, alpha-lactalbumin, bovine serum albumin (BSA), lactoferrin, immunoglobulins, lactoperoxidase enzymes and glycomacropeptides. These proteins perform many functions. Whey proteins provide all essential and branch chain amino acids, improves body composition, immune modulation and have antimicrobial activity. In addition, whey protein has the ability to act as an antioxidant, antihypertensive, antitumor, hypolipidemic, antiviral, antibacterial and chelating agent. It also enhances strength of muscles; prevent osteoporosis and cardiovascular disease (Bjorkmanet al., 2012).
Whey proteins have strong position in sport nutrition. Active people take advantage of whey supplements. Whey proteins are considered as "fast protein", have capability of muscle development during exercise training. Whey protein is also used in enriching some baking products (Rostamiet al.; 2013). The amino acid composition of these proteins is similar to that of skeletal muscle so they are directly involved in muscle anabolism along with growth and repair. Amino acids provided by whey proteins are efficiently utilized and absorbed. Supplementation of whey proteins provides a higher lean body mass gain and favorable effect on protein metabolism as compared to an iso-nitrogenous casein protein ( Cribb, 2006).

Whey and whey proteins also found application in poultry feeding. Whey and its products have been reported to contain unidentified growth factor(s) when added to the diet of chickens. Different researches reported that supplementation of liquid whey, up to a certain level, improves broiler growth. Broiler became lactose intolerant at higher concentration of liquid whey (because of the presence of lactose in whey). This condition causes osmotic diarrhea that lower broiler weight (Al-sadiet al., 2008). Shariatmadari and Forbes. (2005) concluded through various experiments that at least 1.8 parts of whey added to dry food (wet feeding), or whey offered as drinking liquid by diluted with an equal volume of water or used undiluted whey at alternative days with water, were all possibilities for taking advantage of this by-product. Supplementation of commercial whey protein concentrates at two levels i.e. $8 \mathrm{~g} \mathrm{Kg}^{-1}$ and $32 \mathrm{~g} \mathrm{Kg}^{-1}$ increased carcass yield as compared to control group. However, higher level showed better growth performance (Szczureket al.,2013).

Whey proteins can be concentrated and isolated through various techniques including ionic selection (including ion-exchange chromatography, gel filtration) and membrane filtration (ultrafiltration, reverse osmosis, gel permeation), polarity base separation (high performance liquid chromatography). Many of these techniques are not applicable in all cases due to the high cost of equipment, poor yield, less productivity and less selectivity during processing. It cannot be affordable for small industries (Jimenez et al., 2012). Combination of $\mathrm{pH}$, heat and chemical treatment is a technique of protein precipitation to avoid the cost of advance technologies. A number of studies reported that chemicals like $\mathrm{NaCl}$, $\mathrm{CaCl}_{2}$, heat treatment up to $100^{\circ} \mathrm{C}$ and $\mathrm{pH}$ adjustment usually 4 to 7 were used for 
the precipitation of whey proteins (Bordenave-Juchereauet al., 2005; O'Kennedy and Mounsey, 2009; Stanciucet al., 2012).

The present research was designed to utilize futile whey by forming whey protein concentrates (WPCs) through a combination of $\mathrm{pH}$, heat and chemical treatment. Keeping in view the lactose intolerance of broiler, implemented method reduce lactose content in WPCs as compare to whey powder that had higher lactose content. The amino acid profile of these proteins compelled to study the impact of these proteins on broiler growth performance by supplementation at minimum level.

\section{MATERIAL AND METHODS}

Research was conducted according to the following steps. 1) Preparation of whey protein concentrates (WPCs) from cheese whey 2) Bird housing and WPC supplementation in feed 3) Data recording regarding growth performance 4) Statistical analysis

1. Whey was collected during cheese processing from Technology Transfer Center (Processing Hall) National Institute of Food Science and Technology, University of Agriculture, Faisalabad (Pakistan). Whey was chemically treated by the addition of $6 \mathrm{mM} \mathrm{CaCl}_{2} @ 6 \mathrm{~mL}$ per liter of whey and $\mathrm{pH}$ was adjusted to 7 by $1 \mathrm{~N} \mathrm{NaOH}$. After chemical addition, it was heated to $90^{\circ} \mathrm{C}$ for $20 \mathrm{~min}$ proteins were denatured and precipitated. Muslin cloth was used for the filtration of precipitates. Most of soluble components, especially lactose was removed as filtrate and whey protein left as retentate. These retentates were WPC (creamy texture), stored in freezer for supplementation in treatment C. For treatment B, WPC (creamy texture) was dried at $43^{\circ} \mathrm{C}$ by spreading on aluminum foil. After drying, hard crumbles were ground to fine powder. This was WPC (powder); stored in polythene bag for supplementation in treatment B. Both WPCs were analyzed for its protein content by using Kjeldhal's method (AOAC, 2000).

2. Forty five broiler birds (Hubbard strain), day old, of mixed sexes were purchased from a local hatchery. The chicks were weighed and randomly divided into three experimental units A, B and C with three replications each. The birds were placed and reared in deep litter pens each dimension 5 x $3 \times 2.5$ feet, which were disinfect and white washed before the start of the experiment. A layer of two inches saw dust was used as litter material in each pen which was stirred regularly during experiment to keep it in dry condition. Birds were vaccinated against ND and IBD disease Commercially available starter (1-3 week) and finisher (4-5 week) rations were used. Feed of each experimental unit was manually supplemented with WPCs on a weekly basis. Birds had free access to feed and water throughout the experimental period. A treatment plan is elaborated in Table 1.Some growth performance parameters like feed consumption, birds' weight, weight gain and feed conversion ratio were recorded on a weekly basis. Performance of fifth week was recorded after five days instead of seven. After 35 days, one bird from each pen was slaughtered according to Islamic Halaal Principles and weights of carcasses and its different cuts were recorded. Blood samples were collected from wing vein two days before slaughtering and sent to Rehmat Laboratory, Faisalabad (Pakistan) for analysis.

3. Weekly data was analyzed LSD under two factor factorial by using Statistic 8.0 software while after slaughter parameters and hematological parameters were analyzed by using CRD with LSD.

Table 1Treatment plan for supplementation

\begin{tabular}{lcc}
\hline Treatment & Feed & Water \\
\hline A & Normal feed & Fresh clean \\
(control group) & No protein supplementation & water \\
B & Supplementation of WPC (powder) & Fresh clean \\
& $0.2 \%$ & water \\
C & Supplementation of WPC (creamy) & Fresh clean \\
& $2 \%$ & water \\
\hline
\end{tabular}

\section{RESULTS AND DISCUSSION}

Protein content in raw whey varied from $0.5-0.9 \%$. Amount of protein in WPC (creamy texture) increased to $21 \%$ after filtration while it was further increased to $40 \%$ in WPC (powder). Amount of protein in WPC (creamy) was compared to ricotta cheese because of its processing and appearance in accordance with ricotta cheese (El-Sheikh et al., 2010) while WPC (powder) had a wide range having a protein content i.e.35-80\% (Bylund, 1995). Protein content of present finding was in the prescribed range.

Weekly growth performance parameters live bird weight, weight gain, feed intake and FCR depicted in Figure 1, 2, 3 and 4 respectively. In figures mean values sharing different subscript differ significantly. It was observed that supplementation of WPCs did not exhibit any significant effect on body weight, weight gain and feed intake from 1-3 week but at $4^{\text {th }}$ and $5^{\text {th }}$ week statistical analysis showed significant difference. It was evident that treatment A and B were significantly differing from each other while mean values of treatment $C$ was in between the mean values of treatment $\mathrm{A}$ and $\mathrm{B}$. Amount of protein in treatment $C$ was less than treatment $B$ that is why mean values of treatment $C$ were higher than treatment A but less than treatment B. Supplementation of whey proteins did not exhibit any significant difference on FCR. A little variation had been observed in different treatment groups, but the overall impact was nonsignificant. Findings of the present study showed an agreement with Torki and Molanapour (2005), Karimi (2006), Omara (2012) and Abroet al. (2012). But the results of FCR were different from Szczureket al. (2013). who reported that incorporation of whey protein concentrates at the rate of $32 \mathrm{~g}$ per $\mathrm{Kg}$ had a significant effect on FCR. It might be due to higher level of WPCs that exhibit significant impact on FCR.

Parameters regarding different carcass traits were presented in Table 2. Maximum increase in carcass, breast, and heart, wings, thigh and drumstick weight were observed in treatment $\mathrm{B}$. Treatment $\mathrm{C}$ also showed an increase in above mentioned parameters than treatment $\mathrm{A}$ (controlled group) but less than treatment B. Non-significant difference had been observed in GIT, GIT/Carcass ratio, body fat and liver weight. Amino acid profile of whey proteins is similar to that of skeletal muscles that is why they are directly involved in muscle anabolism (Cribbet al. 2006). Present research also showed that it was an amino acid profile of whey protein, which exhibited significant impact on wings, thigh, and breast and drumstick muscles. Majewskaet al. (2009). conveyed that supplementation of liquid whey increase carcass and thigh weight. Similar findings were shown by Salahuddinet al. (2012). where $20 \%$ additional protein increase dressed, leg and breast weight. In the study of Huwaidaet al. (2013). only $2 \%$ difference of protein level in feed resulted an increase in the live bird, carcass, drumstick, thigh, chest, back and wing weight. Supplement WPC @ 8g and $32 \mathrm{~g}$ per kilogram of feed that increase breast meat yield while liver weight was not affected (Szczureket al., 2013). Abroet al. (2012). stated that replacement of plant protein with animal protein had no significant effect on heart weight while Huwaidaet al. (2013). indicated that heart weight increased with a high proportion of protein.

Blood image is good signal of health status of animals. It helps to identify the severity of infection and the indirect signal of immune status of the birds. Present research reported (Table 3) that supplementation did not distress hemoglobin, polymorphnuclear leukocytes (PMN), lymphocytes and pack cell volume (PCV) while it increased number of white blood cells and platelets. Increase in the number of platelets is a healthy sign. It was due to bioactive components of whey proteins but a higher number of white blood cells indicated sign of any disease. Ahmed et al. (1994), Donkohet al. (1999), Odunsiet al. (1999). reported that hematological parameters were unchanged in protein treatment. Reason behind increase in WBC might be temperature fluctuation during storage. WPC is a sensitive product, especially creamy textured WPC. It was stored in the freezer, but due to unavoidable load shedding it undergoes temperature fluctuation that might cause undesirable changes in it and highest number of white blood cells in treatment B so it is recommended that try to use fresh creamy texture WPC to avoid any harmful effect on hematology. WPC (powder) was preferred to dry in constant temperature to avoid any undesirable changes.

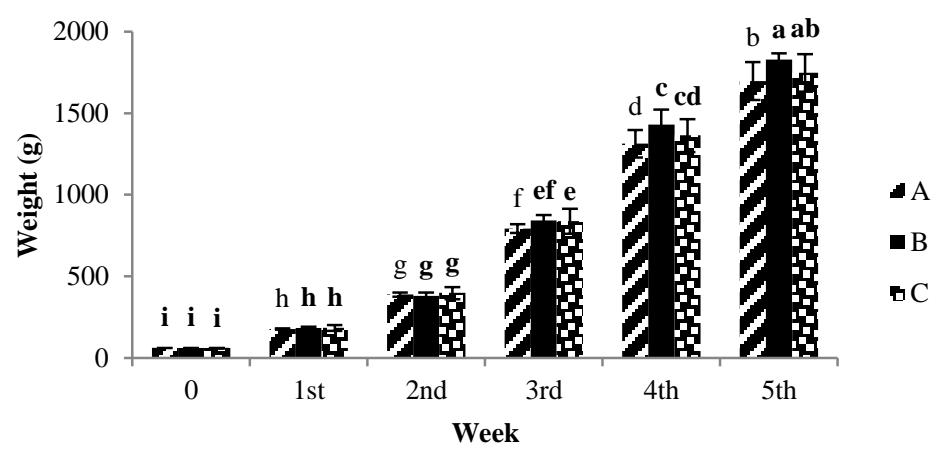

Figure 1 Comparison of means of weekly live bird weight of broiler $\mathrm{A}=$ Normal feed (controlled)

$\mathrm{B}=$ Feed supplement with $0.2 \%$ whey protein (powder)

$\mathrm{C}=$ Feed supplement with $2 \%$ whey protein concentrate (creamy) 


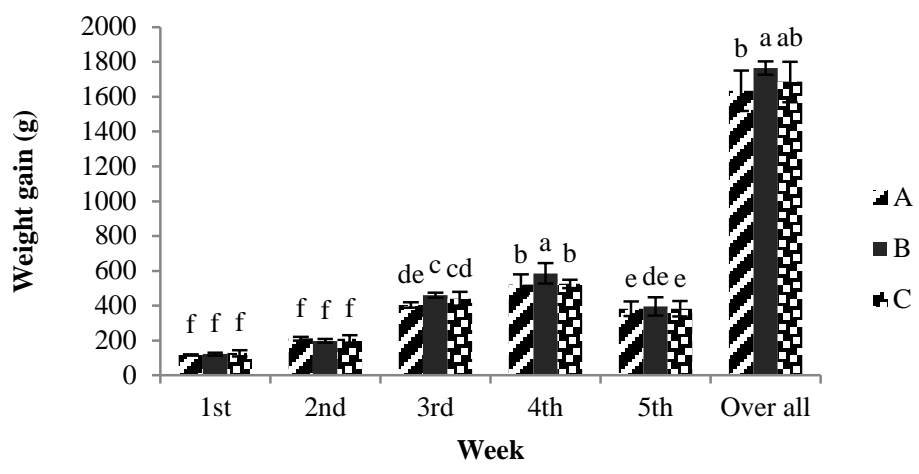

Figure 2 Comparison of means of weekly weight gain of broiler $\mathrm{A}=$ Normal feed (controlled)

$\mathrm{B}=$ Feed supplement with $0.2 \%$ whey protein (powder)

$\mathrm{C}=$ Feed supplement with $2 \%$ whey protein concentrate (creamy)

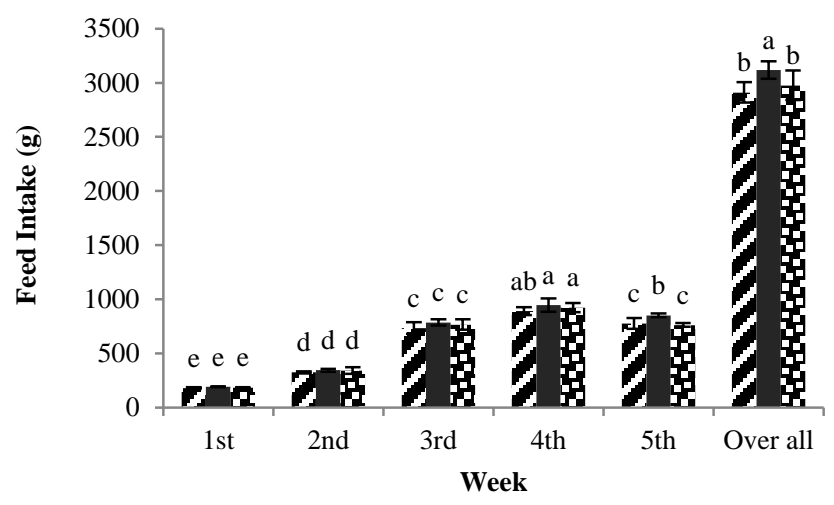

Figure 3 Comparison of means of weekly feed intake of broiler $A=$ Normal feed (controlled)

$\mathrm{B}=$ Feed supplement with $0.2 \%$ whey protein (powder)

$\mathrm{C}=$ Feed supplement with $2 \%$ whey protein concentrate (creamy)

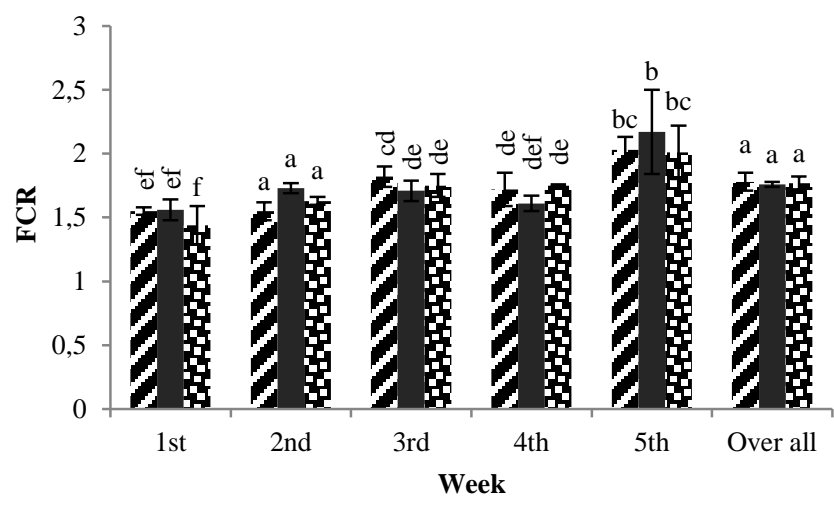

Figure 4 Comparison of means of weekly FCR of broiler $\mathrm{A}=$ Normal feed (controlled)

$\mathrm{B}=$ Feed supplement with $0.2 \%$ whey protein (powder)

$\mathrm{C}=$ Feed supplement with $2 \%$ whey protein concentrate (creamy)
Table 2 Comparison of means \pm SD of carcass traits

\begin{tabular}{|c|c|c|c|c|}
\hline Parameters & \multicolumn{2}{|c|}{$\mathbf{A}$} & B & C \\
\hline Carcass weight & \multicolumn{2}{|c|}{$1018 \pm 0.04^{\mathrm{b}}$} & $1235 \pm 0.029^{\mathrm{a}}$ & $1083 \pm 0.06^{\mathrm{b}}$ \\
\hline GIT weight & \multicolumn{2}{|c|}{$89.16 \pm 5.20$} & $101.66 \pm 2.88$ & $86.6 \pm 12.58$ \\
\hline Ratio GIT/carcass & \multicolumn{2}{|c|}{$0.087 \pm 0.006$} & $0.082 \pm 0.002$ & $0.08 \pm 0.01$ \\
\hline Breast weight & \multicolumn{2}{|c|}{$320 \pm 12.21^{\mathrm{b}}$} & $396 \pm 12.219^{\mathrm{a}}$ & $348 \pm 7.49^{b}$ \\
\hline Heart weight & \multicolumn{2}{|c|}{$7.06 \pm 0.23^{\mathrm{b}}$} & $9.63 \pm 1.2^{\mathrm{a}}$ & $7.33 \pm 0.73^{b}$ \\
\hline Wings weight & \multicolumn{2}{|c|}{$43.60 \pm 0.79^{\mathrm{b}}$} & $51.76 \pm 0.83^{\mathrm{a}}$ & $45.2 \pm 3.04^{\mathrm{b}}$ \\
\hline Thigh weight & \multicolumn{2}{|c|}{$73.53 \pm 3.37^{\mathrm{b}}$} & $923 \pm 4.40^{\mathrm{a}}$ & $81.33 \pm 5.50^{\mathrm{b}}$ \\
\hline Drum stick weight & \multicolumn{2}{|c|}{$72.78 \pm 3.57^{\mathrm{b}}$} & $85.25 \pm 3.48^{\mathrm{a}}$ & $75.43 \pm 8.83^{\mathrm{ab}}$ \\
\hline Body fat weight & \multicolumn{2}{|c|}{$28.267 \pm 4.86$} & $37.03 \pm 7.07$ & $33.23 \pm 6.54$ \\
\hline Liver weight & \multicolumn{2}{|c|}{$35 \pm 5.96$} & $45 \pm 4.86$ & $43 \pm 3.18$ \\
\hline \multicolumn{2}{|l|}{ Parameters } & & B & $\mathbf{C}$ \\
\hline Hemoglobin (g/dL) & & $8.9 \pm 1.29$ & $7.9 \pm 1.49$ & $10.08 \pm 1.19$ \\
\hline $\begin{array}{l}\text { Polymorphnuclear } \\
\text { (PMN) }\end{array}$ & cytes & $7 \pm 3.27$ & $5.6 \pm 2.02$ & $4.17 \pm 2.02$ \\
\hline $\begin{array}{l}\text { White Blood } \\
\text { (thousands } / \mathrm{mm}^{3} \text { ) }\end{array}$ & \multirow[t]{2}{*}{ Cells } & $8133 \pm 2931^{\mathrm{b}}$ & $14866 \pm 3695^{\mathrm{a}}$ & $15833 \pm 2010^{\mathrm{ab}}$ \\
\hline Platelets & & $9833 \pm 1892^{\mathrm{b}}$ & $15500 \pm 1527^{\mathrm{a}}$ & $12400 \pm 2291^{\mathrm{ab}}$ \\
\hline Lymphocytes (\%) & \multicolumn{2}{|r|}{$91.16 \pm 2.84$} & $90.33 \pm 0.28$ & $93.33 \pm 2.25$ \\
\hline Pack Cell Volume (PCV) & \multicolumn{2}{|r|}{$28.72 \pm 4.73$} & $26.08 \pm 3.79$ & $28.72 \pm 4.83$ \\
\hline
\end{tabular}

\section{CONCLUSION}

To date, whey protein concentration (WPC) and its derivatives have not only considered as a good source of essential amino acids but they are a good source of protein substitution in many feeing and food products as well. In case of feeing livestock with a nutrient source like mentioned whey products, it is also effecting on different parameters like, protein amounts of carcasses. WPC is sensitive product especially creamy textured WPC. It was stored in freezer but due to unavoidable load shedding it undergoes temperature fluctuation that might cause undesirable changes in it and highest number of white blood cells in treatment B so it is recommended that try to use fresh creamy texture WPC to avoid any harmful effect on hematology. WPC (powder) was preferred to dry in consistent temperature to avoid any undesirable changes.

\section{REFERENCES}

Abro .,R., Sahito, H. A., Memon, A., Soomro, R.N., Soomro,H. \&Ujjan, N.A 2012. Effect of various protein source feed ingredients on the growth performance of broiler. Int. J. Med. Plant. Res. 1: 38:44.

Ahmed MK, AR Barque, H Nawaz and RH Siddique, 1994.Effect of varying energy and protein levels on the hematology of Japanese quails.Pak. Vet. J. 14: 200-202.

C Al-Sadi, A.N., Al-Kabbi, H.T., Kalf,A.K. \&Amjad, A.A.(2008).Effect of supplemental fresh liquid whey to drinking water on broiler performance.Iraqi. $J$. Poult. Sci. 3: 121-127.

AOAC.(2000). Official Method of Analysis: The Association of Official Analytical Chemists. 17th Ed, Arlington, USA.

Bjorkman, M.P., Finne-Soveri,H. \&Tilvis, R.S.(2012). Whey protein supplementation in nursing home residents A randomized controlled trial. Eur.Geriatr. Med. 3: 161-166.https://doi.org/10.1016/j.eurger.2012.03.010.

Bordenave-Juchereau, S., Almeida, B., Piot,J.M.\&Sannier, F.(2005). Effect of protein concentration, $\mathrm{pH}$, lactose content and pasteurization on thermal gelation of acid caprine whey protein concentrates. J.Dairy.Resea. 72: 34 38.https://doi.org/10.1017/s0022029904000482.

Bylund, G.(1995). Whey processing In: Dairy Processing Handbook, Tetra Pak Processing Systems Lund, Sweden, pp: 331-352.

Cribb, P.J., Williams, M.F, Carey, \& Hayes, A.(2006). The effect of whey isolate and resistance training on strength, body composition and plasma glutamine.Int J. Sport.Nutr.Exerc.Metab. 16: 494-509.https://doi.org/10.1123/ijsnem.16.5.494. Donkoh, A., Atuahene, C.C., Anang,D.M. \&Ofori, S.K.(1999).Chemical composition of solar-dried blood meal and its effect on performance of broiler chickens.Anim. Feed. Sci. Tech. 81: 299-307.https://doi.org/10.1016/s03778401(99)00069-3.

El-Sheikh, M., Farrag,A. \&Zaghloul, A.(2010). Ricotta cheese from whey protein concentrate. J. Am. Sci. 6: 321-325.

Huwaida, E.E.M., Rashid, H.O.S., Yousif,I.A. \&Elamin, K.M. (2013). Effect of dietary protein level and strain on carcass characteristics of heat stressed broiler 
chicks. Agric. Biol. J. N. Am. 4: 504-

511.https://doi.org/10.3923/ijps.2012.649.653.

Jimenez, X.T., Cuenca, A.A., Jurado, A.T., Corona,A.A. \&Urista, C.R.M.(2012)

Traditional Methods for Whey Protein Isolation and Concentration: Effects on

Nutritional Properties and Biological Activity. J. Mex. Chem. Soc. 56: 369-377.

Karimi, A.(2006). The effects of varying fishmeal inclusion levels (\%) on

performance of broiler chicks.Int. J.Poult.Sci. 5:

255:258.https://doi.org/10.3923/ijps.2006.255.258

Majewska, T., Pudyszaki, K., Kozłowski, K., Bohdziewicz,K. \&Matusevicius,

P.(2009).Whey and lactic acid in broiler chickens nutrition.VeterinarijairZootechnika (vet med zoot).47: 56-59.

O'Kennedy,B.T.\&Mounsey, J.S.(2009). The dominating effect of ionic strength on the heat-induced denaturation and aggregation of b-lactoglobulin in simulated $\begin{array}{lllll}\text { milk } & \text { ultrafiltrate.Int. } & \text { Dairy. } & J & 19\end{array}$ 128.https://doi.org/10.1016/j.idairyj.2008.09.004

Odunsi, A.A., Onifade,A.A.\&Babatunde, G.M.(1999). Response of broiler chicks to virginimycin and dietary protein concentrations in the humid tropics.Archivosdezootunia. 48: 317-325.

Omara, I.I.(2012). Nutritive value of skimmed milk and whey, added as natural probiotic in broiler diet. Egyptian. J. Anim. Prod. 49: 207:217.

Rostami, O., Shariaty,M. A., MousaviKhaneghah, A. (2013). Comparison the Effects of, Modified Ultra Filtered Cheese Whey, Whey Concentrate and Milk powders on the Rheological and Sensory Properties of Dough and Taftoon Bread. Global. J. Med. Plant.Resea. 1(1): 106-110.

Salahuddin, M., Uddin,M.\& Ahmad, N.(2012). Effects of protein and vitamin on growth performance and haemato-biochemical profile in broiler. Bangl. J. Vet. Med. 10: 9-14.https://doi.org/10.3329/bjvm.v10i1-2.15640

Shariatmadari, F. \& Forbes, J.M. (2005).Performance of broiler chickens given whey in the food and/or drinking water.Br.Poult. Sci. 46: 498505.https://doi.org/10.1080/00071660500190900

Smithers, G.W.(2008). Whey and whey proteins-from 'gutter-to-gold'.Int .Dairy. J. 18: 695-704.https://doi.org/10.1016/j.idairyj.2008.03.008

Stanciuc, N., Rapeanu, G.,Bahrim,G.\&Aprodu,I.(2012). pH and heat-induced structural changes of bovine apo-a-lactalbumin. Food Chem. 131: 956963.https://doi.org/10.1016/j.foodchem.2011.09.087

Szczurek, W., Szymczyk, B., Arczewska-Włosek, A., Jozefiak, D. \&Alloui, M.N.(2013). The effects of dietary whey protein concentrate level on performance, selected intestinal tract and blood parameters and thiobarbituric acid reactive substances in the liver and breast meat of broiler chickens. J. Anim. Feed. Sci. 22: 342-353.https://doi.org/10.22358/jafs/65923/2013

Torki.M. \&Molanapour, B.(2005). Effect of dried whey and probiotic supplementation on growth performance in broilers. In: Proceedings of the 15th European Symposium on poultry nutrition, Balatonfüred, Hungary pg: 3 